\title{
Effect of electroacupuncture to prevent selenite-induced cataract in Wistar rats
}

\author{
Efeito da eletro-acupuntura na prevenção da catarata induzida por \\ selenito de sódio em ratos Wistar
}

\author{
Angelino Julio Cariello' \\ Fábio Henrique Casanova ${ }^{2}$ \\ Acácio Alves de Souza Lima Filho ${ }^{3}$ \\ Yara Juliano $^{4}$ \\ Angela Tabosa ${ }^{5}$
}

Trabalho realizado no Laboratório de Pesquisas Experimentais em Acupuntura do Departamento de Ortopedia e Traumatologia e no Departamento de Oftalmologia da Universidade Federal de São Paulo/Escola Paulista de Medicina - UNIFESP/EPM - São Paulo (SP) - Brasil.

${ }^{1}$ Médico oftalmologista pela Universidade Federal de São Paulo/Escola Paulista de Medicina - UNIFESP/ EPM - São Paulo (SP) - Brasil.

2 Doutor em medicina pela UNIFESP/EPM - São Paulo (SP) - Brasil. Pós-doutorado pela Universidade de Harvard - EUA.

${ }^{3}$ Doutor em ciências visuais pela UNIFESP/EPM - São Paulo (SP) - Brasil.

${ }^{4}$ Doutora em ciências pela UNIFESP/EPM - São Paulo (SP) - Brasil.

${ }^{5}$ Doutora em neurociências pela UNIFESP/EPM - São Paulo (SP) - Brasil

Corresponding authors:

Angelino Julio Cariello and Angela Tabosa

2045 Vergueiro St., flat 1003 ZIP 04101-000

São Paulo, SP, Brazil

Phone: +55 11 5549-0503 / Fax: + 5511 5539-7537

E-mail: atabosa@uol.com.br

E-mail: angelino65@yahoo.com

Recebido para publicação em 04.08.2005

Aprovação em 15.01.2006

Nota Editorial: Depois de concluída a análise do artigo sob sigilo editorial e com a anuência do Dr. Sérgio Kwitko sobre a divulgação de seu nome como revisor, agradecemos sua participação neste processo.

\begin{tabular}{l} 
ABSTRACT \\
\hline Purpose: To investigate whether electroacupuncture can prevent seleni- \\
te-induced cataract in an experimental model. Methods: Fifty Wistar rat \\
pups were randomized into 5 groups of 10 animals: Group 1 (control), no \\
procedure was performed; Group 2 (selenite), sodium selenite (30 micro- \\
moles/kg body weight) was injected subcutaneously between postpartum \\
days 10 to 12; Group 3 (anesthesia) received the same dose of selenite \\
and underwent ether inhalation anesthesia during 10 minutes daily for \\
one week; Group 4 (electroacupuncture) underwent the same procedure \\
of Group 3, but also receiving electroacupuncture (2 Hz, 50 mA) applied \\
to the Neiguan (PC6) and Guangming (GB37) acupoints during the \\
anesthesia period; and Group 5 (Sham) underwent the same procedures \\
of Group 4, but needles were applied to non-acupoints. The development \\
of cataract was assessed one week later, and its density was graded by \\
slit lamp biomicroscopy. Results: All control rats lenses (Group 1) were \\
clear. Groups 2, 3 and 5 rats developed more severe cataract or complete \\
opacification. In Group 4 (electroacupuncture), 45\% of eyes did not \\
develop cataract while thirty per cent developed less severe cataract than \\
Groups 2, 3 and 5. The between-group difference was statistically \\
significant (p<0.001). Lens opacification grade in Groups 1 and 4 was \\
lower than in the Groups 2, 3 and 5 (p<0.001). Conclusion: Electroacu- \\
puncture effectively decreased selenite-induced cataract formation rate \\
in pup rats when needles were applied at specific acupoints. \\
\hline
\end{tabular}

Keywords: Cataract; Antioxidants; Electroacupuncture; Free radicals; Rats, Wistar

Cataract is the main cause of blindness worldwide. Currently the only form of treatment is surgical removal of the opacified lens ${ }^{(1-2)}$. It is estimated that a delay of 10 years in the development of the cataract would reduce the necessity for surgery in $45 \%$, saving millions. Also, even after cataract surgery, some postoperative-related complications might occur such as posterior capsular opacity, uveitis, glaucoma, cystoid macular edema, error in intraocular lens power calculation, retinal detachment, corneal edema or endophthalmitis ${ }^{(3-4)}$.

The opacification of the crystalline occurs by aggregation of cytoplasmic lens proteins due to modifications in the intermolecular interactions that are the result of chemical actions that include oxidative stress, glycation, proteolysis, transamidation, phosphorylation and increase of the calcium levels ${ }^{(5)}$. Theoretically, conditions that influence these chemical ac- 
tions like antioxidant reagents would inhibit the attractive forces, being able to delay or to prevent the protein aggregation and the opacification ${ }^{(6-7)}$.

Acupuncture has been performed by inserting fine metallic needles at specific loci of the human body, which may be manipulated manually or by electrical stimulation (electroacupuncture $)^{(8)}$. Its effects are based on secretion of neurotransmitters (e.g., endorphins, dynorphins, serotonin, kinins) within neural synapses in the spinal cord and central nervous system, which cause reduction in pain threshold, vasodilation and muscular relaxation ${ }^{(9-10)}$. According to some Chinese authors, many ocular disorders could be treated with acupuncture (e.g., dry eye, allergic conjunctivitis, glaucoma, and cataract) and many textbooks covering acupuncture specialization courses recommend some acupoints for the treatment and prevention of cataract ${ }^{(11-15)}$. However there is only anecdotal basis to support this treatment modality and its real benefits are not known. The aim of this study is to evaluate the effect of the electroacupuncture preventing sodium-selenite-induced cataract in an experimental model.

\section{METHODS}

Five pregnant Wistar-albino rats were obtained from the Center of Development of Experimental Models for Medicine and Biology (CEDEME) at the Federal University of São Paulo, Paulista School of Medicine (UNIFESP - EPM) in São Paulo, Brazil. All experiments were performed in accordance with the ARVO Statement for the use of Animals in Ophthalmic and Vision Research and "Guiding Principles in the Care and Use of Animals"(16-17). The experimental protocol was approved by the Research Ethics Committee of the university.

Each Wistar albino female rat and its litter of 10 pups were housed in plastic cages and remained in a separate animal room with adequate air turnover, constant control of temperature $\left(22^{\circ} \mathrm{C}\right)$, lighting was set for 12-hour on and 12-hour off, receiving standard rat chow (Purina-Nuvilab, São Paulo, Brazil) and water ad libitum. At 10-12 days of age, two pups from each female rat were randomized into five groups of 10 animals each, as follows:

In Group 1, Control group, no specific procedure was performed. In Group 2, Selenite group, cataracts were induced by a single subcutaneous injection of sodium selenite (Ophthalmos Ltda., São Paulo, Brazil) ( $30 \mu \mathrm{mol} / \mathrm{kg}$ body weight) to $10-$ 12-day-old rat pups as previously described ${ }^{(5)}$. In Group 3, Anesthesia group, the same amount of sodium selenite was injected and rats underwent inhalation of ethyl ether (Quimesp, São Paulo, Brazil) anesthesia for 10 minutes daily for one week. In Group 4, Electroacupuncture group, pups underwent the same procedure as in Group 3, but also receiving electroacupuncture by an electrical stimulator Plexus AP 585 WMV $2 \mathrm{~Hz}, 50$ mA (Biotherapy, São Carlos, Brazil) once a day applied to acupuncture needles $(0.25 \mathrm{~mm} \times 15 \mathrm{~mm} /$ LautzBrazil) which were inserted in the equivalent of the human acupoints Neiguan (PC-6) at the ventral face of the wrist and Guangming (GB37) at the lateral face of hind limbs bilateral$1 y^{(11)}$ during the anesthesia period for one week. These points were chosen based on traditional Chinese medicine meridian theory ${ }^{(14)}$. Finally, in Group 5, Sham group, rats underwent the same procedure as in Group 4, but the needles were applied to the non-acupoint situated bilaterally in the posterior region of shoulders (PC-6 sham point) and another at the same level of GB-37 but on the medial face of the hind limbs (GB-37 sham point). All animals were weighed daily and were examined one week after the initial procedures.

The development of cataract was assessed after one week by slit lamp examination (Zeiss model SL-10, Carl Zeiss Meditec, Germany). One of the authors (AJC), blinded regarding the studied groups, performed all slit lamp examinations. The pupils were dilated with a drop of a 1:1 mixture of $1 \%$ tropicamide and 10\% phenylephrine hydrochloride (Ophthalmos Ltda, São Paulo, Brazil) and the development of cataract was graded by a scale of zero to 6 , as previously described ${ }^{(18)}$ and used by many authors ${ }^{(19-23)}$. After slit lamp evaluation all animals were sacrificed by ethyl ether inhalation and their carcasses and all contaminated bedding material were collected by the municipal company (LIMPURB, São Paulo, Brazil) for subsequent incineration, according to guidelines of the Committee of Chemical Residues of UNIFESP - EPM.

Statistical analysis of the data was carried out using the Kruskal-Wallis analysis of variance to analyze the development of the cataract and weight in independent groups, and Friedman test for comparison between the groups. The results were expressed as mean \pm standard deviation. A p value less than 0.05 was considered statistically significant. All statistics in this study were performed using SPSS for Windows, version 11.0.

\section{RESULTS}

Both male and female 10-12-day-old Wistar albino rats were used. There was no statistically significant difference between genders $(\mathrm{p}=0.934)$. Table 1 shows cataract grade distribution by group. All control rats lenses (Group 1) were clear - stage zero (Figure 1A). Eight of ten rats (16 eyes, $80 \%$ ) in Group 2 (Selenite group) developed bilateral stage 5 cataract (Figure 1B), whereas one rat developed a bilateral stage 4 , and another a bilateral stage 6. In Group 3 (Anesthesia group) $70 \%$ of eyes (14 eyes) had a stage 5 cataract (Figure 1C), and $30 \%$ (6 eyes) presented as stage 4.

In rats treated with electroacupuncture (Group 4), no cataract was observed in 9 eyes (45\% of eyes) (Figure 1D), while two eyes developed a stage 1 cataract (10\%), one eye stage 2 $(5 \%)$, one eye stage $3(5 \%)$, two eyes stage $4(10 \%)$, and the remaining five eyes had stage 5 cataract $(25 \%)$. On the other hand, seventy per cent of pups' eyes (14 eyes) in Group 5 (Sham group) developed stage 5 cataract (Figure 1E), ten per cent ( 2 eyes) had stage 6 , and twenty per cent ( 4 eyes), stage 


\begin{tabular}{|c|c|c|c|c|c|c|c|c|c|c|}
\hline \multirow[b]{2}{*}{ Group } & \multirow[b]{2}{*}{$\mathbf{N}$} & \multicolumn{7}{|c|}{ Cataract classification } & \multirow[b]{2}{*}{ Mean \pm SD } & \multirow[b]{2}{*}{ Median } \\
\hline & & Stage zero & Stage 1 & Stage 2 & Stage 3 & Stage 4 & Stage 5 & Stage 6 & & \\
\hline Control & 20 & 20 & 0 & 0 & 0 & 0 & 0 & 0 & $0.00 \pm 0.00$ & 0.00 \\
\hline Selenite & 20 & 0 & 0 & 0 & 0 & 2 & 16 & 2 & $5.00 \pm 0.46$ & 5.00 \\
\hline Anesthesia & 20 & 0 & 0 & 0 & 0 & 6 & 14 & 0 & $4.70 \pm 0.47$ & 5.00 \\
\hline Electroacupuncture & 20 & 9 & 2 & 1 & 1 & 5 & 2 & 0 & $1.85 \pm 2.01^{*}$ & 1.00 \\
\hline Sham & 20 & 0 & 0 & 0 & 0 & 4 & 14 & 2 & $4.90 \pm 0.55$ & 5.00 \\
\hline Total & 100 & 29 & 2 & 1 & 1 & 17 & 46 & 4 & $3.29 \pm 2.24$ & 4.50 \\
\hline
\end{tabular}

4. There was no statistically significant difference in cataract formation between right and left eye in all groups.

The between-group difference was statistically significant $(\mathrm{p}<0.001)$. The mean lens opacification grade in Groups 1 and 4 was significantly lower than that in Groups 2, 3 and 5 $(p<0.001)$. Figure 1 shows clinical aspect for each group highlighting the most representative finding.

As a measure of toxicity, the body weight of the rats in each group was daily measured and compared. All rats presented increase of body weight during the course of the experiments and there was no statistically significant difference between the groups ( $\mathrm{p}=0.184$ ). Table 2 shows the difference of the percentage of weight gain between baseline and one week after therapy using the median and mean \pm standard deviation. No side effects were noticed on acupuncture or selenite treatment, except for occasional skin atrophy at the selenite injection site.

\section{DISCUSSION}

In accordance with the previous studies ${ }^{(5)}$, a single injection of selenite (Group 2) resulted in the formation of $100 \%$ nuclear cataracts by day 7 after selenite treatment in our study. Groups 1 and 2 acted as normality and disease controls, respectively, allowing exclusion of environmental interaction or absence of the effect of the drug. Group 3 was important to exclude the possible interference of anesthetic drug effect. In Group 5, non-acupoints were chosen near real points on the upper and lower members to confirm the effectiveness of acupoints according to the traditional Chinese theory. Our results demonstrated that daily electroacupuncture treatment prevented or inhibited opacification in a rat model for cataract formation in most of the cases. The variability in the response in Group 4 may indicate that acupuncture has an individual susceptibility factor in the treatment.

Acupuncture theory suggests many other acupoints to treat cataract, including systemic and local points. In this study were used only two systemic acupoints bilaterally, and no local points, because it would not be possible to insert many needles in these little rat pups due to anatomical conditions.

With regard to cataract, the selenite model was selected because of the rapid, effective and reproducible cataract for- mation. Although the rate of opacification in the selenite model is much more rapid than in human cataract, it has many general similarities to human cataract like increased calcium, protein aggregation, decreased water soluble proteins and level of reduced glutathione ${ }^{(5,24)}$. A study using confocal microscopy and a lipid membrane probe suggested that morpho-

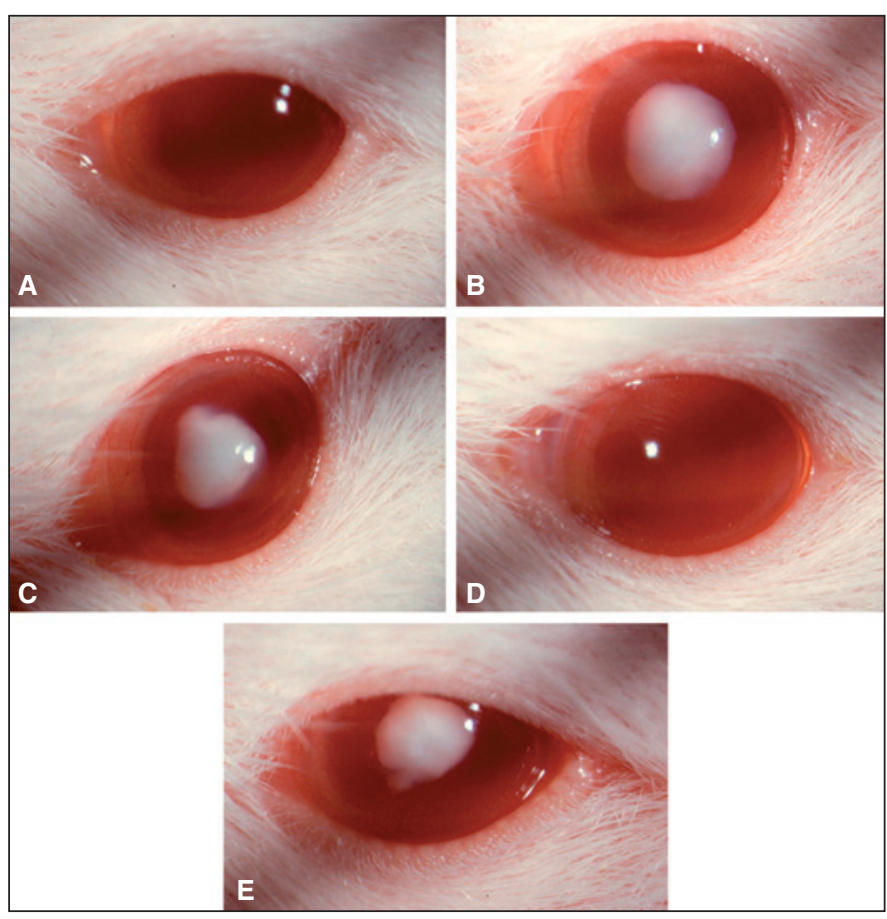

Figure 1 - Cataract formation observed in one sample from each group. A: control group; B: selenite group; C: anesthesia group; D: electroacupuncture group; E: sham group

\begin{tabular}{|c|c|c|c|}
\hline Group & $\mathbf{N}$ & Mean (\%) & Median (\%) \\
\hline Control & 20 & 34.14 & 31.41 \\
\hline Selenite & 20 & 35.76 & 36.67 \\
\hline Anesthesia & 20 & 25.43 & 30.33 \\
\hline Electroacupuncture & 20 & 30.25 & 31.25 \\
\hline Sham & 20 & 26.36 & 28.17 \\
\hline Total & 100 & 30.38 & 31.25 \\
\hline
\end{tabular}


logical changes in the nucleus of the human cataractous lens were best approximated by those seen in the selenite model $^{(25)}$.

Free radicals secondary to cell metabolism and photochemical reaction have the potential to damage lipids, proteins and nucleic acids. The lens presents antioxidant mechanisms like ascorbate, catalase and glutathione systems to protect against oxidative stress ${ }^{(26)}$. A reduction in the activity or level of these antioxidants occurs in old age and causes cumulative damage that leads to formation of senile cataract ${ }^{(27)}$. Some studies suggest that selenite probably acts as an oxidative agent $^{(28-29)}$.

Wang et al. demonstrated that electroacupuncture could regulate the production and clearance of free radicals decreasing the contents of nitric oxide and malondialdehyde and increasing the activities of superoxide dismutase and glutathione peroxidase ${ }^{(30)}$. Pogosyan et al. found improvement in the antioxidant status of erythrocytes after acupuncture treatment measuring contents or activities of several antioxidants including the glutathione system ${ }^{(31)}$. Electroacupuncture probably would act modulating the concentration or activities of antioxidants in lens cell.

Several free radical scavenger and antioxidant substances, such as pantethine, caffeic acid phenethyl ester, WR-77913, flavonoids and disulfiram have been tested in experimental research for the prevention of cataract in animal models with satisfactory results ${ }^{(19-23,32)}$ but for reasons of effectiveness and safety, these drugs have not been studied yet for human senile cataracts. Conversely, acupuncture is a practical and cheap therapeutic modality and, when applied by a trained acupuncturist with standard disinfection method, has a very low adverse effect rate ${ }^{(33)}$.

Längle et al., found that systemic intake of SDZ ICT 322, a selective serotonin receptor antagonist, induced cataract in rats, suggesting possible interference of neurotransmitters in cataract development $^{(34)}$. Some animal data and clinical observations suggest that acupuncture modulates activities in the central nervous system and influences treatment areas via release of neurotransmitters or hormones, or even by direct modulation of neural pathway ${ }^{(35-36)}$. Secretion of many neurotransmitters has been associated with acupuncture mechanisms like endorphins, dynorphins, serotonin, catecholamines ${ }^{(37)}$. It is possible that acupuncture plays a neurohumoral role in preventing cataract.

Although the prevalence of acupuncture use has increased in the western world, scientific data about its efficacy and mechanisms is scarce; mainly in the ophthalmologic area ${ }^{(38)}$. This experimental study is the first step in the scientific research to evaluate the effect of acupuncture on prevention of cataract. It was performed according to scientific criteria and represents a new subject for future research. Cataract is a primary cause of human blindness and prevention should be the most important therapeutic approach for this disease. The results of the present study cannot be interpreted as evidence that acupuncture can protect humans from cataract; therefore it is necessary to carry out further experimental studies to elucidate the mechanisms involved in this kind of therapy and clinical trials involving humans to support this hypothesis.

\section{RESUMO}

Objetivo: Avaliar o efeito da eletro-acupuntura na prevenção da catarata induzida por selenito de sódio em modelo experimental. Método: Cinqüenta filhotes de ratos Wistar foram randomizados em 5 grupos: no Grupo 1 (Controle, $n=10$ ) nenhum procedimento foi realizado. Grupo 2 (Selenito, $n=10$ ), selenito de sódio (30 $\mu$ moles $/ \mathrm{kg}$ ) foi injetado por via subcutânea no décimo dia de vida. No Grupo 3 (Anestesia, $n=10$ ), filhotes receberam a mesma dose de selenito e sofreram anestesia inalatória com éter etílico durante 10 minutos diariamente por 1 semana. Grupo 4 (eletro-acupuntura, n=10), os animais sofreram os mesmos procedimentos do Grupo 3, porém também receberam eletro-acupuntura $(2 \mathrm{~Hz}, 50 \mathrm{~mA})$ aplicada nos pontos Neiguan (PC 6) e Guangming (GB37) durante o período de anestesia. Grupo 5 (Sham, $\mathrm{n}=10$ ), os ratos foram submetidos aos mesmos procedimentos que o Grupo 4, porém as agulhas foram aplicadas em pontos falsos. O desenvolvimento da catarata foi avaliado após uma semana por lâmpada de fenda. Resultados: Todos os animais controles (Grupo 1) não desenvolveram catarata. Todos os ratos dos grupos 2, 3 e 5 desenvolveram catarata grave. No Grupo 4 (eletro-acupuntura), $45 \%$ dos olhos não desenvolveram catarata e trinta por cento desenvolveram catarata menos grave que aos Grupos 2 , 3 e 5 . A diferença entre os grupos foi estatisticamente significante $(\mathrm{p}<0,001)$. A média do grau de opacificação do cristalino nos Grupos 1 e 4 foi mais baixo que nos Grupos 2, 3 e 5 $(\mathrm{p}<0,001)$. Conclusão: Eletro-acupuntura diminuiu a taxa de formação de catarata induzida por selenito em filhotes de ratos quando as agulhas foram aplicadas em pontos de acupuntura específicos.

Descritores: Catarata; Antioxidantes; Eletro-acupuntura; Radicais livres; Ratos Wistar

\section{REFERENCES}

1. Leske MC, Chylack LT Jr, Wu SY. The Lens Opacities Case-Control Study. Risk factors for cataract. Arch Ophthalmol. 1991;109(2):244-51.

2. Jacques PF. The potential preventive effects of vitamins for cataract and age-related macular degeneration. Int J Vitam Nutr Res. 1999;69(3):198-205. Review.

3. Bunce GE. Antioxidant nutrition and cataract in women: a prospective study. Nutr Rev. 1993;51(3):84-6. Review.

4. Taylor A, Jacques PF, Epstein EM. Relations among aging, antioxidant status, and cataract. Am J Clin Nutr. 1995;62(6 Suppl):1439S-1447S. Review.

5. Shearer TR, Ma H, Fukiage C, Azuma M. Selenite nuclear cataract: review of the model. Mol Vis. 1997;3:8. Review.

6. Clark JI, Benedek GB. The effects of glycols, aldehydes, and acrylamide on phase separation and opacification in the calf lens. Invest Ophthalmol Vis Sci. 1980;19(7):771-6.

7. Clark JI. Lens cytoplasmic protein solutions: analysis of a biologically occurring aqueous phase separation. Methods Enzymol. 1994;228:525-37. 
8. NIH Consensus Conference. Acupuncture. JAMA. 1998;280(17):1518-24. Review.

9. Riederer P, Tenk H, Werner H, Bischko J, Rett A, Krisper H. Manipulation of neurotransmitters by acupuncture (?) (A preliminary communication). J Neural Transm. 1975;37(1):81-94

10. Yamamura Y, Mello LEAM, Tabosa A, Cricenti SV, DiDio LJA. Acupuncture: physiologic effects explained on a neuroanatomical and neurophysiological basis. Rev Paul Acupunt. 1997:3(1):14-8.

11. Yamamura Y. Acupuntura tradicional: a arte de inserir. 2a ed. São Paulo: Roca; 2001.

12. Ross J, Zang FU. The organ systems of traditional Chinese medicine. 2nd ed. London: Churchill Livingstone; 1989.

13. Maciocia G. The foundations of Chinese medicine: a comprehensive text for acupuncturists and herbalists. Edinburgh: Churchill Livingstone; 1996.

14. Bensky D, O'Connor J. Acupuncture: a comprehensive text. Chicago: Eastland Press; 1981

15. Dabov S, Goutoranov G, Ivanova R, Petkova N. Clinical application of acupuncture in ophthalmology. Acupunct Electrother Res. 1985;10(1-2):79-93.

16. National Institute of Health. Public health service policy on human care and use of laboratory animals [text on the Internet]. Betesda 2002 Available from: http:/ /grants1.nih.gov/grants/olaw/references/PHSPolicyLabAnimals.pdf

17. ARVO statement for the use of animals in ophthalmic and visual research [text on the Internet]. Rockville, MD: The Association for Research in Vision and Ophthalmology (ARVO); 2006. Available from: http://www.arvo.org/AboutARVO/ animalst.asp

18. Hiraoka T, Clark JI. Inhibition of lens opacification during the early stages of cataract formation. Invest Ophthalmol Vis Sci. 1995;36(12):2550-5.

19. Clark JI, Livesey JC, Steele JE. Delay or inhibition of rat lens opacification using pantethine and WR-77913. Exp Eye Res. 1996;62(1):75-84.

20. Hiraoka T, Clark JI, Li XY, Thurston GM. Effect of selected anti-cataract agents on opacification in the selenite cataract model. Exp Eye Res. 1996;62(1):11-9.

21. Thiagarajan G, Chandani S, Sundari CS, Rao SH, Kulkarni AV, Balasubramanian D. Antioxidant properties of green and black tea, and their potential ability to retard the progression of eye lens cataract. Exp Eye Res. 2001;73(3):393-401.

22. Yilmaz G, Demirel-Yilmaz E, Turan B. Disulfonic stilbene prevents seleniteinduced cataract in rat pup lens. Biol Trace Elem Res. 2000;75(1-3):129-38.

23. Doganay S, Turkoz Y, Evereklioglu C, Er H, Bozaran M, Ozerol E. Use of caffeic acid phenethyl ester to prevent sodium-selenite-induced cataract in rat eyes. J Cataract Refract Surg. 2002;28(8):1457-62.
24. Shearer TR, Anderson RS, Britton JL, Palmer EA. Early development of selenium-induced cataract: slit lamp evaluation. Exp Eye Res. 1983;36(6):781-8.

25. Boyle DL, Blunt DS, Takemoto LJ. Confocal microscopy of cataracts from animal model systems: relevance to human nuclear cataract. Exp Eye Res. 1997;64(4):565-72.

26. Lerman S. Free radical damage and defense mechanisms in the ocular lens. Lens Eye Toxic Res. 1992;9(1):9-24. Review.

27. Boulton M, Saxby LA. Age changes. In: Yanoff M, Duker JS, editors. Ophthalmology. 2nd ed. St. Louis: Mosby; 2004.

28. Gupta SK, Trivedi D, Srivastava S, Joshi S, Halder N, Verma SD. Lycopene attenuates oxidative stress induced experimental cataract development: an in vitro and in vivo study. Nutrition. 2003;19(9):794-9.

29. Bunce GE, Hess JL. Biochemical changes associated with selenite-induced cataract in the rat. Exp Eye Res. 1981;33(5):505-14.

30. Wang L, Tang C, Lai X. Effects of electroacupuncture on learning, memory and formation system of free radicals in brain tissues of vascular dementia model rats. J Tradit Chin Med. 2004;24(2):140-3.

31. Pogosyan AS, Venediktova NI, Kosenko EA, Kaminskii YG. Antioxidant status of erythrocytes after acupuncture treatment. Bull Exp Biol Med. 2004;138(1):26-9.

32. Nabekura T, Koizumi Y, Nakao M, Tomohiro M, Inomata M, Ito Y. Delay of cataract development in hereditary cataract UPL rats by disulfiram and aminoguanidine. Exp Eye Res. 2003;76(2):169-74.

33. Ernst G, Strzyz H, Hagmeister H. Incidence of adverse effects during acupuncture therapy - a multicentre survey. Complement Ther Med. 2003;11(2):93-7.

34. Langle UW, Wolf A, Kammuller ME. Cataractogenic effects in rats following chronic administration of SDZ ICT 322, a selective 5-HT3 antagonist. Fundam Appl Toxicol. 1993;21(3):393-401.

35. Shen J. Research on the neurophysiological mechanisms of acupuncture: review of selected studies and methodological issues. J Altern Complement Med. 2001;7 Supp11:S121-7. Review.

36. Kiser RS, Khatami MJ, Gatchel RJ, Huang XY, Bhatia K, Altshuler KZ. Acupuncture relief of chronic pain syndrome correlates with increased plasma met-enkephalin concentrations. Lancet. 1983;2(8364):1394-6.

37. Ma SX. Neurobiology of Acupuncture: Toward CAM. Evid Based Complement Alternat Med. 2004;1(1):41-7.

38. Rhee DJ, Katz LJ, Spaeth GL, Myers JS. Complementary and alternative medicine for glaucoma. Surv Ophthalmol. 2001;46(1):43-55. Review.

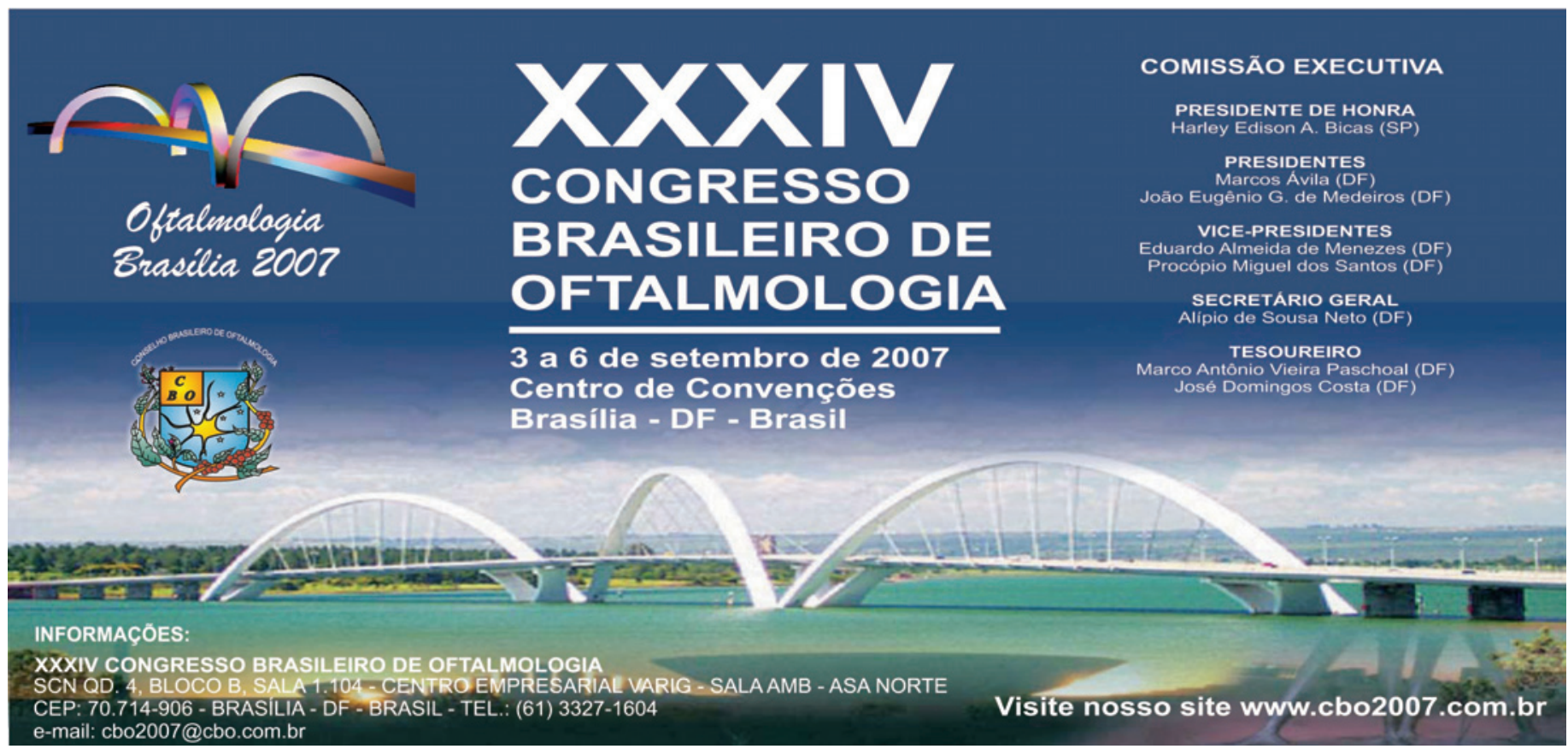

